\title{
PENYELESAIAN SENGKETA BATAS ANTAR DAERAH
}

\author{
Andre Junianto Patongloan \\ Dr. Marthen B. Salinding, S.H., M.H \\ Dr. Basri, S.H., M.Kn
}

\begin{abstract}
Inter regional Border Dispute Resolution by Andre Junianto Patongloan and guided by Dr. Marthen B. Salinding , SH, MH and Dr. Basri, SH, M.Kn. In a study of this, the formulation of the problem that is raised among others: 1. Urgency Affirmation of Region in the Formation of Territory, 2. Efforts Law Against Settlement Dispute Regional Boundaries. The study is intended to examine is normative and examine the issue of the legal use of the principles of law as well as by using a methodology approach to regulation law - law (statue approach) and the approach of the case (case approach). That regional autonomy is a promising manifestation for the region, which is tight relation to the boundaries of the area that was in the area of autonomous mentioned. Problems boundary area has a dimension that is very complex, such as; conflict social, conflict sources of the power of nature, conflict ethnicity/culture /ethnicity and so forth. Completion tiered by the Governor and the Minister in the State,is a form of public law in the name of the state. The role of the Governor and the Minister in the State shows the behavior of active state, as affirmed in the principle of the modern state.

Form of settlement of disputes boundary region between regions as part of the implementation of the functions of government found their Autonom organs of government (vrijbevoegdheid, discretionary or Freiesermessen ), this is because the regulatory legislation that no load norms are vague (voge norm), the norm is open (open norm ) or contains a choice (choice). In this case it must be understood that what is done by a government organ is not in a capacity as a function of hearing or as a function of legislation. Settlement of disputes boundary region between regions that pursued by the mechanism of the law of the country through the agency of justice whichThere has been expected to provide legal certainty and a sense of justice. In preventing the confusion of the conflict norm on several levels of regulation law for the settlement of disputes boundary region between regions. the principle of cooperation between regions can be relied upon to translate legal certainty and provide a sense fair for the government area in order to organize and manage the limits of its territory as one of the supporting creation of the implementation of the autonomous regions that good.
\end{abstract}

Keyword : Establishment of Regional, Local Limits, Settlement Dispute . 


\section{PENDAHULUAN}

Otonomi Daerah adalah perwujudan dari pemancaran kekuasaan oleh pusat kepada daerah. Dimana seringkali muncul persoalan-persoalan sosial di daerah tak terkecuali persoalan batas antar daerah, cara penentuan batas wilayah haruslah memenuhi aspek yuridis dan teknis di lapangan, ketika ini tidak dapat dipenuhi maka akan timbul sengketa. Penyelesaian berjenjang oleh Menteri Dalam Negeri dan Gubernur adalah bentuk penyelesaian secara politik pemerintahan dan bersifat final. Penyelesaian berjenjang oleh Menteri Dalam Negeri dan Gubernur adalah wujud perbuatan hukum publik atas nama negara. Peran Menteri Dalam Negeri dan Gubernur menunjukkan perilaku aktif negara sebagaimana ditegaskan dalam prinsip negara modern, yang merupakan bentuk penyelesaian batas wilayah antar daerah sebagai bagian dari penyelenggaraan fungsi pemerintahan. Ini dikarenakan peraturan perundang-undangan yang ada memuat norma atau mengandung pilihan, dalam hal ini harus dipahami bahwa apa yang dilakukan oleh pemerintah tidak dalam kapasitas sebagai fungsi mengadili ataupun sebagai fungsi legislasi.

Sebagai sebuah negara, Indonesia memiliki wilayah-wilayah yang tunduk pada yurudiksi nasionalnya. Hal ini ditegaskan dalam pasal 25A Undang-Undang Dasar Negara Republik Indonesia Tahun 1945, yaitu ; "Negara kesatuan Republik Indonesia adalah negara kepulauan yang berciri nusantara dengan wilayah yang batas-batas dan hak-haknya ditetapkan dengan undang-undang". Terdapat 3 (tiga) aspek penting yang terkait dalam penetapan batas wilayah sebuah negara, yaitu;
a. Masalah kepastian hukum,
b. Penegakan hukum, dan
c. Eksplorasi dan eksploitasi.

Sejak berlakunya Undang-Undang Nomor 22 Tahun 1999, Indonesia masuk dalam babak baru yaitu era otonomi daerah. Daerah otonom diberi kewenangan dengan prinsip luas, nyata dan bertanggung jawab. Yang mana kemudian undang- undang tersebut diganti dengan Undang-Undang Nomor 32 Tahun 2004 dan yang terakhir dengan Undang-Undang Nomor 23 Tahun 2014 tentang Pemerintahan Daerah. Daerah Otonom adalah kesatuan 
masyarakat hukum yang mempunyai batas-batas wilayah yang berwenang mengatur dan mengurus urusan pemerintahan dan kepentingan masyarakat setempat menurut prakarsa sendiri berdasarkan aspirasi masyarakat dalam sistem Negara Kesatuan Republik Indonesia.

Berbagai implikasi kemudian muncul karena implementasi undang-undang tersebut, satu diantaranya yaitu bahwa daerah memandang sangat pentingnya penegasan batas daerah. Salah satu penyebabya dikarenakan daerah memiliki kewenangan untuk mengelola sumber daya di wilayahnya. Daerah dituntut untuk berperan aktif dalam mengeksploitasi dan mengeksplorasi sumber daya di daerahnya. Kemampuan daerah dalam mengoptimalkan sumber daya yang ada menjadi penentu bagi daerah dalam menjalankan otonomi daerah. Oleh karena itu daerah-daerah menjadi terdorong untuk mengetahui secara pasti sampai sejauh mana wilayah kewenangannya, terutama yang memiliki potensi sumber daya yang mendukung Pendapatan Asli Daerah (PAD). Faktor strategis lainnya yang menyebabkan batas daerah menjadi sangat penting adalah karena batas daerah mempengaruhi luas wilayah daerah yang merupakan salah satu unsur dalam perhitungan Dana Alokasi Umum (DAU) dan bagi hasil sumber daya alam (SDA).

Daerah melaksanakan kewenangan masing-masing dalam lingkup batas daerah yang ditentukan, artinya kewenangan suatu daerah pada dasarnya tidak boleh melampaui batas daerah yang ditetapkan dalam peraturan perundang- undangan. Apabila batas daerah tidak jelas akan menyebabkan dua kemungkinan akibat negatif. Pertama, suatu bagian wilayah dapat diabaikan oleh masing- masing daerah karena merasa itu bukan daerahnya atau dengan kata lain masing- masing daerah saling melempar tanggung jawab dalam menyelenggarakan pemerintahan, pelayanan masyarakat maupun pembangunan di bagian wilayah tersebut. Kedua, daerah yang satu dapat dianggap melampaui batas kewenangan daerah yang lain sehingga berpotensi timbulnya konflik antar daerah.

Beberapa kasus sengketa batas wilayah antar daerah yang pernah diselesaikan melalui proses peradilan sebagai berikut;

a. Mahkamah Agung, dalam putusan Nomor: 01.P/HUM/2012, Tanggal 2 Mei 2012, mengabulkan permohonan keberatan Hak Uji Materiil dari para pemohon (Gubernur 
Kalimantan Selatan, Ketua DPRD Kalimantan Selatan, Bupati Kota Baru, Ketua DPRD Kota Baru, dkk) terhadap Peraturan Menteri Dalam Negeri Nomor 43 Tahun 2011, tanggal 29 September 2011 tentang Wilayah Administrasi Pulau Lereklerekan, terkait permohonan ini Mahkamah Agung dalam amarnya mengatakan bahwa Pulau Lereklerekan termasuk wilayah administratif kabupaten Kota Baru provinsi Kalimantan Selatan dan tidak termasuk wilayah administratif provinsi Sulawesi Barat; ${ }^{1}$

b. Mahkamah Konstitusi, memeriksa, mengadili dan selanjutnya dalam amar putusannya mengabulkan permohonan untuk seluruhnya, oleh pemohon a.n Daria (Bupati Lingga provinsi kepulauan Riau), Kisanjaya (Camat Singkep kabupaten Lingga) dan Saref (kepala desa Berhala) tentang Pengujian Penjelasan pasal 3 Undang Undang Nomor 5 tahun 2002 tentang Pembentukan provinsi kepulauan Riau terkait sengketa pulau Berhala, dasar putusan Mahkamah Konstitusi mengacu kepada putusan uji materiil Mahkamah Agung Nomor: 49.P/HUM/2011, tanggal 9 Februari 2011 yang telah menetapkan pulau Berhala merupakan bagian dari wilayah kabupaten Lingga provinsi Kepulauan Riau. Adapun permohonan yang dimohonkan oleh Gubernur Riau Mohammad Sani, M.A., saat itu, Mahkamah Agung membatalkan Peraturan Menteri Dalam Negeri Nomor 44 Tahun 2011 tentang Wilayah Administrasi pulau Berhala adalah termasuk bagian wilayah dari kabupaten Tanjung Jabung Timur provinsi Jambi;2 "menyatakan mengabulkan gugatan Penggugat untuk seluruhnya", Pemohon oleh Bupati Kediri dengan tergugat Gubernur Jawa Timur dan Bupati Blitar. ${ }^{3}$

Kekaburan batas daerah mungkin juga dapat menimbulkan dampak negatif yang lebih luas lagi dari sekedar potensi konflik antar daerah karena potensi strategis dan ekonomis suatu bagian wilayah, seperti dampak pada kehidupan sosial dan penyelenggaraan administrasi pemerintahan bahkan mungkin juga menimbulkan dampak politis khususnya di daerah-daerah perbatasan. Oleh karena itu dalam penyelenggaraan administrasi

\footnotetext{
${ }^{1}$ Direktorat Putusan Mahkamah Agung Republik Indonesia putusan.mahkamahagung.go.id.

2 Direktorat Putusan Mahkamah Konstitusi RepublikIndonesia putusan.mahkamahkonstitusi.go.id.

37 Direktorat Putusan Mahkamah Agung Republik Indonesia putusan.mahkamahagung.go.id
} 
pemerintahan, penegasan batas daerah menjadi penting untuk dilaksanakan. Apabila disimak secara cermat mengenai permasalahan sengketa tapal batas wilayah administratif antar daerah yang banyak terjadi Indonesia terkait dengan penataan otonomi daerah maka ini merupakan suatu ancaman serius bagi disintegrasi bangsa ke depan.

\section{RUMUSAN MASALAH}

Berdasarkan hal-hal yang tersebut diatas, maka dalam penelitian ini ada dua permasalahan yang akan dianalisis ;

1. Urgensi Penegasan Batas Daerah Dalam Pembentukan Wilayah,

2. Upaya Hukum Terhadap Penyelesaian Sengketa Batas Daerah.

\section{III.METODE PENELITIAN}

Berdasarkan latar belakang dan rumusan masalah dalam penelitian ini, maka penelitian ini merupakan Penelitian Normatif. Hal ini didasarkan pada pertimbangan bahwa titik acuan dalam penelitian ini adalah analisis Urgensi Batas Daerah Dalam Pembentukan Suatu Wilayah dan Upaya Hukum Terhadap Penyelesaian Sengketa Batas Daerah yang meliputi proses hukum melalui Peradilan Tata Usaha Negara (PTUN), Mahkamah Agung (MA) dan Mahkamah Konstitusi (MK).

\section{HASIL PENELITIAN PEMBAHASAN}

\section{A. Urgensi Penegasan Batas Daerah Dalam Pembentukan Wilayah}

Pemekaran wilayah menjadi salah satu hal yang menarik dalam otonomi daerah. Tujuan dari pemekaran wilayah tentu saja untuk menjadikan wilayah hasil pemekaran menjadi lebih maju dan mensejahterakan masyarakatnya. Semakin banyak wilayah yang mengalami pemekaran, maka keberadaan batas antar wilayah yang berdekatan menjadi cukup penting untuk diselesaikan.

Pemerintah telah mengatur hal-hal yang berkaitan dengan batas daerah pada beberapa produk hukum. Diantaranya Undang-undang Nomor 9 Tahun 2015 tentang Perubahan 
Kedua Atas Undang-undang Nomor 23 Tahun 2014 tentang Pemerintahan Daerah yang merupakan perubahan dari Undang-undang Nomor 32 Tahun 2004 tentang Pemerintahan Daerah. Serta Peraturan Menteri Dalam Negeri Nomor 141 Tahun 2017 tentang Penegasan batas Daerah merupakan tindak lanjut atas Undang-undang 23 Tahun 2014. Pada awalnya pemekaran daerah didasarkan pada Undang-undang Nomor 22 Tahun 1999 tentang Pemerintahan Daerah. Dalam ketentuan Pasal 5 ayat (2) disebutkan bahwa daerah dapat dimekarkan menjadi lebih dari satu daerah. Namun, setelah Undang-undang Nomor 22 Tahun 1999 diganti dengan Undang- undang Nomor 32 Tahun 2004 tentang Pemerintahan Daerah, ketentuan mengenai pemekaran wilayah tercantum pada Pasal 4 ayat (3) dan ayat (4), istilah yang dipakai adalah Pemekaran Daerah, yang berarti pengembangan dari satu daerah otonom menjadi dua atau lebih daerah otonom. Dalam Pasal 4 ayat (3) Undangundang Nomor 32 Tahun 2004 tersebut dinyatakan: "Pembentukan daerah dapat berupa penggabungan beberapa daerah atau bagian daerah yang bersandingan atau pemekaran dari satu daerah menjadi dua daerah atau lebih". Sedangkan dalam Pasal 4 ayat (4) undangundang tersebut dinyatakan: "Pemekaran dari satu daerah menjadi 2 (dua) daerah atau lebih sebagaimana dimaksud pada ayat (3) dapat dilakukan setelah mencapai batas minimal usia penyelenggaraan pemerintahan".

Secara lebih khusus, Undang-undang Nomor 32 Tahun 2004 mengatur ketentuan mengenai pembentukan daerah dalam Bab II tentang Pembentukan Daerah dan Kawasan Khusus. Dalam konteks itu, pemekaran wilayah juga termasuk dalam ruang lingkup pembentukan daerah. Undang-undang ini juga menentukan bahwa pembentukan suatu daerah harus ditetapkan dengan undang- undang tersendiri. Ketentuan ini tercantum dalam Pasal 4 ayat (1). Kemudian, ayat (2) pasal yang sama menyebutkan bahwa: "Undang-undang pembentukan daerah sebagaimana dimaksud pada ayat (1) antara lain mencakup nama, cakupan wilayah, batas, ibukota, kewenangan menyelenggarakan urusan pemerintahan, penunjukan penjabat kepala daerah, pengisian keanggotaan DPRD, pengalihan kepegawaian, pendanaan, peralatan, dokumen, serta perangkat daerah". Ketentuan normatif sebagaimana diatur dalam Pasal 4 ayat (2) Undang-undang Nomor 32 Tahun 2004 tersebut, pada prakteknya dilakukan secara makro, yakni hanya menyebutkan persyaratan kewilayahan yang hanya menyebutkan batas-batas wilayahnya saja. Kondisi ini pada tingkat 
operasionalnya menimbulkan persoalan demarkasi yang serius, yakni menyangkut titik-titik patok perbatasan daerah.

Demarkasi merupakan langkah teknis dalam penentuan batas-batas wilayah yang ditandai dengan pemasangan patok dan sejenisnya ${ }^{4}$. Dalam beberapa penelitian sebelumnya terlihat, bahwa maraknya kasus sengketa batas wilayah tersebut dipicu oleh salah satunya ketidakjelasan batas-batas wilayah administratif antara daerah otonom baru dengan wilayah lama. Persoalan ini kemudian merambah ke berbagai konflik dimensional seperti konflik sosial dan konflik Sumber Daya Alam.

Secara empiris, terdapat sejumlah kasus sengketa batas daerah baik yang diakibatkan pemekaran daerah otonom baru yang melibatkan daerah lama dengan daerah baru. Sebagai contoh, data dari Kementerian Dalam Negeri mencatat hingga tahun 2018, segmen batas antar daerah di seluruh Indonesia mencapai 977 segmen yang terdiri dari 812 segmen batas dalam wilayah provinsi dan 165 Segmen lintas provinsi, Penyelesaian segmen batas antar daerah di seluruh wilayah Indonesia, masih jadi tantangan pemerintah pusat. ${ }^{5}$

Diantara sekian konflik batas daerah tersebut, sebagian diantaranya berdampak pada timbulnya konflik lain seperti konflik sosial dan konflik sumber daya alam. Ironinya, hingga kini keinginan untuk memekarkan wilayah, mulai dari tingkat keluruhan/desa, kecamatan, kabupaten dan provinsi, masih terus bergulir. Alasannya pun sama yaitu untuk meningkatkan kesejahteraan rakyat dan memperpendek tali birokrasi. ${ }^{6}$ Memetakan beberapa penyebab konflik terkait batas wilayah, antara lain; ${ }^{7}$

\footnotetext{
${ }^{4}$ Prescott, V. dan Triggs, G.D., International Frontiers and Boundaries: Law, Politics and Geography, Martinus Nijhoff Publishers, 2008, h.66.

${ }^{5}$ Nasional.kontan.co.id, 7 Meret 2018, Kementerian Dalam Negeri Kebut Penyelesaian batas Wilayah, https://nasional.kontan.co.id/news/kementerian-dalam-negeri-kebut-penyelesaian- batas-wilayah, diakses Juni 2019

${ }^{6}$ Basomadiong, Pengaruh Pemekaran Wilayah Terhadap Konflik Sosial Masyarakat Lokal, https://basomadiong.wordpress.com/2012/12/25/pengaruh-pemekaran-wilayah-terhadap-konfliksosialmasyarakat-lokal, diakses Juni 2019.

${ }^{7}$ Basomadiong, Pengaruh Pemekaran Wilayah Terhadap Konflik Sosial Masyarakat Lokal, https://basomadiong.wordpress.com/2012/12/25/pengaruh-pemekaran-wilayah-terhadap-konfliksosialmasyarakat-lokal, diakses Juni 2019
} 


\section{Yuridis}

Tidak jelasnya batas daerah dalam lampiran undang-undang dan peta lampiran undangundang yang tidak memenuhi syarat sebagai peta, ketidaksinkronan bunyi pasal dengan peta undang-undang, ketidaksinkronan undang-undang pembentukan daerah yang satu dengan yang lain;

\section{Ekonomi}

Perebutan sumber daya ekonomi (Sumber Daya Alam/SDA, Kawasan Niaga/Transmigrasi, Perkebunan, potensi Pendapatan Asli Daerah/PAD).

\section{Kultural}

Isu terpisahnya etnis atau sub etnis.

4. Politik \& Demografi

Berkaitan dengan sumber daya politik, seperti jumlah pemilih dan perolehan suara bagi anggota Dewan Perwakilan Rakyat Daerah (DPRD) dan Kepala Daerah (KDH)

\section{Sosial}

Munculnya kecemburuan sosial, riwayat konflik masa lalu, isu penduduk asli dan pendatang.

\section{Pemerintahan}

Duplikasi pelayanan pemerintahan, jarak ke pusat pemerintahan, diskriminasi pelayanan, keinginan bergabung ke daerah tetangga.Secara normatif pembentukan sebuah daerah otonom baru sebelum diputuskan secara formal melalui mekanisme politik di Dewan Perwakilan Rakyat yang diwujudkan dalam sebuah undang-undang yang bersifat spesifik, terdapat sejumlah tahapan kegiatan yang mesti dilalui. Tahapan-tahapan dimaksud sejatinya bersifat buttom-up dan demokratis. Hal itu ditandai dengan keharusan normatif untuk mewadahi aspirasi masyarakat dari level yang paling bawah (masyarakat) sampai 
kepada elit-elit politik di Daerah. Ketentuan ini misalnya bisa dilihat dalam Peraturan Pemerintah Nomor 78 Tahun 2007 tentang

Pembentukan, Penghapusan dan Penggabungan Daerah. Dinyatakan bahwa "aspirasi sebagian besar masyarakat setempat dalam bentuk Keputusan Badan Permusyawaratan Desa (BPD) untuk Desa dan Forum Komunikasi Kelurahan atau nama lain untuk Kelurahan di wilayah yang menjadi calon cakupan wilayah provinsi atau kabupaten/kota yang akan dimekarkan"8. Berarti untuk mengusulkan sebuah daerah otonom baru harus dibuktikan dengan adanya dokumen aspirasi masyarakat yang diputuskan melalui BPD. Keputusan tersebut kemudian disampaikan kepada DPRD setempat untuk dilegalkan menjadi keputusan DPRD, yang selanjutnya diajukan kepada Bupati/Wali Kota untuk diputuskan, apakah akan diterima atau ditolak. Keputusan Bupati/Walikota tersebut harus dilandasi oleh kajian terlebih dulu mengenai kelayakannya. Hasil dari proses ini kemudian dinaikkan ke tingkat provinsi untuk mendapatkan persetujuan yang ditandai dengan dikeluarkannya surat keputusan oleh Gubernur dan surat keputusan DPRD Provinsi. Selanjutnya, proses yang harus ditempuh adalah Gubernur mengajukan usulan pemekaran daerah baru tersebut kepada Presiden melalui Menteri dalam Negeri dengan melampirkan9:

1. Hasil kajian daerah;

2. Peta wilayah calon provinsi;

3. Keputusan DPRD Kabupaten/Kota dan Keputusan Bupati/Walikota; dan

4. Keputusan DPRD Provinsi dan Keputusan Gubernur.

Pada tataran implementasinya, keempat persyaratan tersebut di sebagian daerah telah terpenuhi dengan baik, sebagian lagi tidak. Proses politik dalam pembentukan daerah otonom baru yang dilakukan oleh Dewan Perwakilan Daerah RI, sebagai salah satu pihak yang berkompeten dalam proses pemekaran wilayah cukup banyak. Usulan pemekaran daerah yang diproses oleh DPD bersama Dewan Perwakilan Rakyat Daerah. Berdasarkan

\footnotetext{
${ }^{8}$ Pasal 14 huruf (a) Peraturan Pemerintah Nomor 78 Tahun 2007 tentang Pembentukan, Penghapusan dan Penggabungan Daerah.

9 Pasal 14 huruf (f) Peraturan Pemerintah Nomor 78 Tahun 2007 tentang Pembentukan, Penghapusan dan Penggabungan Daerah.
} 
data dari Dirjen Otonomi Daerah, penambahan Daerah Otonom Baru sejak tahun 1999-2014 menunjukkan bahwa selama kurun waktu 15 tahun tersebut perjalanan otonomi daerah, telah melahirkan sebanyak 220 daerah otonom baru dengan rincian 8 Provinsi, 178 Kabupaten dan 34 Kota.

\section{B. Upaya Hukum Terhadap Penyelesaian Sengketa Batas Daerah}

\section{Penyelesaian Sengketa Batas Wilayah Antar Daerah Melalui Peradilan Tata Usaha Negara}

Peradilan Tata Usaha Negara mempunyai kewenangan menyelesaikan sengketasengketa tata usaha negara, yang memenuhi unsur-unsur yang diisyaratkan. Sengketa tata usaha negara baru lahir jikalau seseorang atau badan hukum perdata merasa dirugikan, sebagai akibat dikeluarkannya suatu keputusan. Sebagaimana diketahui bahwa, badan/pejabat tata usaha negara dalam fungsi menyelenggarakan kepentingan umum tidak terlepas daripada tindakan mengeluarkan keputusan, sehingga tidak menutup kemungkinan pula keputusan tadi menimbulkan kerugian.

Pasal 1 angka 1 Undang-Undang Peradilan Tata Usaha Negara14 merumuskan: keputusan tata usaha negara adalah penetapan tertulis yang dikeluarkan oleh badan atau pejabat tata usaha negara yang berisi tindakan hukum tata usaha negara yang berlaku yang bersifat konkrit, individual dan final yang menimbulkan akibat hukum bagi seseorang atau badan hukum perdata.

Berkaitan dengan sengketa batas wilayah antar daerah, berdasarkan kompetensi absolut dan kompetensi relatif yang dimiliki, Peradilan Tata Usaha Negara dapat saja memeriksa, mengadili dan memutuskan asalkan objek sengketa yang diajukan benar-benar memenuhi setiap unsur-unsur Keputusan Tata Usaha Negara sesuai pasal 1 angka 3 Undang-Undang Peradilan Tata Usaha Negara serta semua upaya dalam internal penyelenggaraan fungsi pemerintahan telah dilalui namun tidak berhasil. Akan tetapi rasanya itu tidaklah tepat jikalau Peradilan Tata Usaha Negara memiliki kompetensi untuk memeriksa, mengadili dan 
memutus jenis sengketa ini karena mendahului apa yang akan dibahas kemudian setelah bagian ini, sejumlah teori, konsep dan fakta membuktikan itu.

Kasus yang pernah disidangkan melalui Peradilan Tata Usaha Negara yaitu: Gugatan oleh Bupati Kediri kepada Gubernur Jawa Timur dan Bupati Blitar terkait terbitnya objek sengketa Surat Keputusan Gubernur Nomor 188/828/KPTS/013/2014 tanggal 11 Desember 2014 Tentang Pencabutan Atas Keputusan Gubernur Jawa Timur Nomor 188/113/KPTS/013/2012 Tentang Penyelesaian Sengketa Batas Daerah Antara Kabupaten Blitar Dengan Kabupaten Kediri Yang Terletak Pada Kawasan Gunung Kelud Di Provinsi Jawa Timur ke PTUN Surabaya dengan Nomor Perkara 29/G/2015/PTUN-SBY tanggal 12 Februari 2015. Dengan amar putusannya yang menyatakan bahwa "mengabulkan gugatan Penggugat untuk seluruhnya", dalam pertimbangan hukum oleh Majelis Hakim yang diketuai oleh Hakim Anna L. Tewernusa, S.H., menyatakan bahwa "menolak eksepsi tergugat (Gubernur Jawa Timur) dan turut tergugat (Bupati Blitar) dan mengabulkan seluruh gugatan Penggugat (Bupati Kediri) untuk seluruh gugatannya serta mewajibkan tergugat untuk mencabut Surat Keputusan Gubernur Nomor 188/828/KPTS/013/2014, tanggal 11 Desember 2014 Tentang Pencabutan Atas Keputusan Gubernur Jawa Timur Nomor 188/113/KPTS/013/2012, tanggal 28 Februari 2012 Tentang Penyelesaian Sengketa Batas Daerah Antara Kabupaten Blitar Dengan Kabupaten Kediri Yang Terletak Pada Kawasan Gunung Kelud".

Beberapa argumentasi hukum yang dapat dibangun terkait apa yang telah diputuskan oleh PTUN-SBY dalam sengketa batas wilayah dimaksud:

- Berdasarkan ketentuan pasal 53 ayat (1) Undang-Undang nomor 5 tahun 1986 tentang Pengadilan Tata Usaha Negara yang telah diubah kedua kali, sebagaimana diubah terakhir dengan Undang-Undang Nomor 51 tahun 2009, antara lain menegaskan bahwa "orang atau badan hukum yang merasa kepentingannya dirugikan oleh Keputusan Tata Usaha Negara dapat mengajukan gugatan tertulis kepada pengadilan yang berwenang yang berisi tuntutan agar Keputusan Tata Usaha Negara yang disengketakan itu dinyatakan batal atau tidak sah, dengan atau tanpa disertai tuntutan ganti rugi dan/atau rehabilitasbahwa, sedangkan dalam penjelasannya 
menegaskan antara lain: "Badan atau Pejabat Tata Usaha Negara tidak dapat mengajukan gugatan ke Pengadilan Tata Usaha Negara untuk menggugat Keputusan Tata Usaha Negara.

Ini membuktikan bahwa tindakan yang dilakukan oleh Pemerintah Kabupaten Blitar dan Bupati Blitar tidak dapat dijadikan subjek hukum sebagai pengganti Penggugat dalam perkara sengketa batas wilayah antar Kabupaten Blitar dan Kabupaten Kediri.

Dalam sengketa TUN, unsur-unsur KTUN harus lengkap (akumulatif) bukan alternatif. Jadi jika ada salah satu unsur saja KTUN tidak terpenuhi maka itu tidak dapat dijadikan sebagai objek sengketa ke PTUN.

$>$ Surat Keputusan Gubernur Jawa Timur Nomor: 188/828/KPTS/013/2014, tanggal 11 Desember 2014 tentang Status Gunung Kelud “belum bersifat final” sehingga belum memiliki kekuatan hukum mengikat bagi para pihak karena masih tersedia "sarana hukum lain dan/atau lebih tinggi" untuk ditempuh yakni kepada pejabat diatasnya yakni diajukan kepada Menteri Dalam Negeri sebagaimana dalam Peraturan Menteri Dalam Negeri Nomor 141 Tahun 2017 tentang Penegasan Batas Daerah pasal 24 ayat (3).

\section{Penyelesaian Sengketa Batas Wilayah Antar Daerah Melalui Mahkamah Agung}

Mahkamah Agung dapat dianalogikan sebagai puncak perjuangan keadilan bagi setiap warga negara. Hakekat fungsinya berbeda dengan Mahkamah Konstitusi yang tidak berhubungan dengan tuntutan keadilan bagi warga negara. Hal ini dianggap penting dalam rangka perwujudan kekuasaan kehakiman yang menjamin tegaknya negara hukum yang didukung oleh sistem kekuasaan kehakiman yang independen dan impartial. ${ }^{10}$

Bahwa menurut ketentual pasal 24A ayat (1) UUDNRI tahun 1945, menyatakan: "Mahkamah Agung berwenang mengadili pada tingkat kasasi, menguji peraturan perundang-undangan

\footnotetext{
${ }^{10}$ Jimly Asshiddiqie, Konstitusi \& Konstitusionalisme Indonesia, Sinar Grafika, Jakarta, 2009, h.197.
} 
di bawah undang-undang terhadap undang-undang dan mempunyai wewenang lainnya yang diberikan oleh undang- undang". Dan berdasarkan ketentuan pasal 24 ayat (2) UUDNRI tahun 1945, berbunyi: "Kekuasaan Kehakiman dilakukan oleh sebuah Mahkamah Agung dan badan peradilan yang berada dibawahnya dalam lingkungan peradilan umum, lingkungan peradilan agama, lingkungan peradilan militer, lingkungan peradilan tata usaha negara, dan oleh sebuah Mahkamah Konstitusi".

Berkaitan dengan sengketa batas wilayah antar daerah, Mahkamah Agung sebagai lembaga negara yang diberikan kewenangan oleh UUD untuk menguji peraturan perundangundangan di bawah undang-undang terhadap undang- undang. Karena dalam hal penetapan batas wilayah sebuah daerah, Menteri Dalam Negeri berdasarkan kewenangan yang dimilikinya membentuk Peraturan Menteri. Peraturan Menteri adalah satu dari sekian banyak bentuk perundang-undangan yang kedudukannya berada dibawah undangundang. ${ }^{11}$

Yudisial review merupakan pengujian peraturan perundang-undangan yang kewenangannya terbatas kepada lembaga kekuasaan kehakiman, dan tidak tercakup di dalamnya pengujian oleh lembaga legislatif dan eksekutif. Putusan terhadap kasus sengketa batas wilayah antar daerah yang pernah diajukan sebagai Permohonan Hak Uji Materiil ke Mahkamah Agung, antara lain:

Perhatikan Hirarki peraturan perundang-undangan dalam Undang-undang Nomor 12 Tahun 2011 tentang Pembentukan Peraturan Perundang-undangan. Menghukum Termohon keberatan Hak Uji Materiil untuk membayar biaya perkara sebesar Rp. 1.000.000,- (satu juta rupiah).

Peraturan Menteri Dalam Negeri tentang Penegasan Batas Daerah suatu wilayah administratif, merupakan objek pengujian peraturan perundang-undangan yang bersifat mengatur (regeling), yaitu peraturan tertulis yang dibentuk oleh lembaga negara atau

${ }^{11}$ Bagir Manan, Dasar-dasar Perundang-undangan Indonesia, (Jakarta: Indo Hill Co, 1992) 
pejabat yang berwenang dan mengikat secara umum. ${ }^{12}$

Bagir Manan menjelaskan bahwa peraturan perundang-undangan memiliki tiga unsur penting, yaitu: ${ }^{13}$

a. Peraturan perundang-undangan berbentuk keputusan tertulis, sehingga dapat juga disebut hukum tertulis;

b. Peraturan perundang-undangan dibentuk oleh pejabat atau lingkungan jabatan (badan, organ) yang memiliki wewenang membuat peraturan yang berlaku atau mengikat umum;

c. Peraturan perundang-undangan bersifat mengikat secara umum.

Sedangkan suatu keputusan itu dapat dikategorikan sebagai "ketetapan" atau

"beschikking" apabila memenuhi beberapa unsur, yaitu: ${ }^{14}$

a. Keputusan sepihak;

b. Keputusan tersebut adalah tindakan hukum di lapangan hukum publik;

c. Keputusan dibuat oleh badan atau pejabat tata usaha negara;

d. Keputusan mengenai masalah atau keadaan konkret dan individual;

e. Keputusan dimaksudkan untuk mempunyai akibat hukum tertentu, yaitu menciptakan, mengubah, menghentikan, atau membatalkan suatu hubungan hukum.

Dengan demikian dapat dibedakan antara keputusan yang berbentuk peraturan perundang-undangan yang bersifat mengatur (regeling) dan mengikat secara umum dengan keputusan yang bersifat tetap (beschikking). Dalam kaitan pengertian peraturan yang bersifat mengatur dan mengikat secara umum dan ketetapan yang bersifat konkret dan individual, Jimly lebih jelas dalam membedakan keduanya. ${ }^{15}$ Bahkan pengertian peraturan perundang-undangan dirumuskan dengan batasan yang lebih jelas, yaitu "dalam arti khusus

\footnotetext{
12 Zainal Arifin Hoesein, Loc.Cit. h.44-45

13 ibid

14 Ibid

15 (Jakarta: Mahkamah Konstitusi Indonesia dan Pusat Studi Hukum Tata Negara Fakultas Hukum Universitas Indonesia, 2004), h.250-254.
} 
pengertian peraturan perundang-undangan adalah keseluruhan susunan hirarkhis peraturan perundang-undangan yang berbentuk undang-undang ke bawah, yaitu semua produk hukum yang melibatkan peran lembaga perwakilan rakyat bersama-sama dengan pemerintah ataupun melibatkan peran pemerintah karena kedudukan politiknya dalam rangka melaksanakan produk legislatif yang ditetapkan oleh lembaga perwakilan rakyat bersama-sama dengan pemerintah menurut tingkatannya masing-masing". ${ }^{16}$

Dari beberapa amar putusan uji materiil oleh Majelis Hakim Mahkamah Agung dalam perkara sengketa batas wilayah antar daerah, dalam pertimbangan hukumnya, Majelis MA hanya menggunakan parameter pengujian pada peraturan perundang-undangan yang berkaitan langsung dengan sengketa batas wilayah antar daerah, ini terjadi disebabkan Majelis Hakim sebatas berpandangan bahwa Peraturan Menteri Dalam Negeri yang menjadi objek permohonan yang diajukan melalui mekanisme uji materiil adalah jenis peraturan perundang-undangan murni yang pembentukannya adalah sah untuk melaksanakan perintah peraturan lebih tinggi (melaksanakan bunyi ketentuan pasal dalam undangundang) tanpa Majelis melakukan pemilahan secara tepat apakah tindakan Menteri Dalam Negeri membentuk Peraturan Menteri adalah sebagai peraturan perundang-undangan murni ataukah sebagai peraturan kebijakan (beleidsregel) yang kehadirannya adalah sebatas pada doelmatifheid atau manfaatnya untuk mendukung aktivitas penyelenggaraan fungsi pemerintahan. Karena jika Peraturan Menteri Dalam Negeri tentang batas wilayah yang dibentuk adalah untuk tujuan doelmatifheid maka dapat dikategorikan sebagai peraturan kebijakan (beleidsregel) sehingga parameter penilaian bukanlah pada peraturan perundangundangan (perintah tegas peraturan lebih tinggi/undang-undang) tetapi pada Asas-Asas Umum Pemerintahan yang Baik (AAUPB) untuk menilai materi peraturan kebijakan (beleidsregel) dimaksud terdapat penyalahgunaan kewenangan ataukah kesewenangwenangan oleh pembentuknya dalam mencapai AAUPB. Rasionalitas tindakan yang dilakukan oleh Badan atau Pejabat Tata Usaha Negara menjadi kata kunci.

Mengutip pendapat Hadjon dkk, ${ }^{17}$ mengenai penyelesaian sengketa batas wilayah antar

\footnotetext{
${ }^{16} \mathrm{Ibid}$, diambil dari Jimly Assihiddiqie, h.256.

${ }^{17}$ Phillipus M. Hadjon, R. Sri Soemantri Martosoewignjo, Sjahcran Basah, Bagir Manan,
} 
daerah dapat dimasukkan sebagai wujud peraturan-peraturan kebijaksanaan (Beleidsregels, policy rules). Karena dalam pelaksanaan pemerintahan sehari-hari menunjukkan betapa Badan atau Pejabat Tata Usaha Negara acapkali menempuh pelbagai langkah kebijaksanaan tertentu, antara lain menciptakan apa yang kini sering dinamakan "peraturan kebijaksanaan" (beleidsregel, policy rule). Produk semacam peraturan kebijaksanaan ini tidak terlepas dari kaitan penggunaan "freies Ermessen", yaitu Badan atau Pejabat Tata Usaha Negara yang bersangkutan merumuskan kebijaksanaannya itu dalam pelbagai bentuk "jurdische regels", seperti halnya, peraturan, pedoman, pengumuman, surat edaran dan mengumumkan kebijaksanaan itu. Suatu peraturan kebijaksanaan pada hakekatnya merupakan produk dari perbuatan tata usaha negara yang bertujuan "naar buiten gebracht schriftelijk beleid (menampakkan keluar sebuah kebijakan tertulis) namun tanpa disertai kewenangan pembuatan peraturan dari Badan atau Pejabat Tata Usaha Negara yang menciptakan peraturan kebijaksanaan tersebut. Peraturan-peraturan kebijaksanaan dimaksud pada kenyataannya telah merupakan bagian dari kegiatan pemerintahan (bestuuren) dewasa ini.18

Uji materiil peraturan kebijakan oleh eksekutif (excutive review) merupakan mekanisme yang dapat diterapkan tanpa perlu memberikan wewenang atau menginterpretasikan undang-undang karena peraturan kebijakan sebagai bentukan eksekutif dapat diubah atau dibatalkan oleh eksekutif berdasarkan "contraries actur". Uji materiil oleh eksekutif dapat mengacu pada prinsip atau asas yang telah dikemukakan sebelumnya untuk menjadi dasar judicial review. Legislative review peraturan kebijakan, baik peraturan kebijakan formal maupun materiil, tidak mungkin dilakukan karena tidak adanya wewenang untuk melakukan pengujian dan juga konsep peraturan kebijakan merupakan produk eksekutif bukan legislatif. ${ }^{19}$

Menurut Utrecht, pengawasan atas kebijakan dalam suatu tindakan pemerintahan

\footnotetext{
H.M Laica Marzuki, J. B. J. M. Ten Berge, P. J. J. Van Buuren, F. A. M. Stroink, Pengantar Hukum Administrasi Indonesia: Introducing to the Indonesian Administrative Law, Gadjah Mada University Press, Yogyakarta, 1993, h.152-156.

${ }^{18}$ I Victor Emanuel W. Nalle, Konsep Uji Materiil Setara Press (Kelompok Intrans Publishing) Malang, Mei 2013, h.164bid 
(doelmatifheids-controle) tidak dapat diserahkan kepada hakim, tetapi berada pada jajaran pemerintah sendiri. Alasan hakim tidak boleh menilai kebijakan karena dengan menilai kebijakan pemerintah maka hakim seolah-olah duduk sebagai eksekutif.20

Pendapat tersebut juga diadopsi di Indonesia. Kompetensi pengadilan di Indonesia untuk mengadili tindakan pemerintah berdasarkan kebijakan, atas dasar onrechtmatige overheidsdaad, juga dibatasi. MA pernah mengeluarkan Surat Edaran tanggal 25 Februari 1977 nomor MA/Pemb/0159/77 yang menyatakan bahwa perbuatan kebijakan penguasa tidak termasuk kompetensi pengadilan untuk menilainya, kecuali ada unsur sewenangwenang dan penyalahgunaan wewenang. ${ }^{21}$

Kalaupun tindakan pemerintah berdasarkan peraturan kebijakan tersebut digugat di peradilan umum atas dasar onrechtmatife overheidsdaad, terdapat beberapa kendala yang terkait spesialisasi hakim. Menurut Phillipus M. Hadjon, perkara-perkara terkait onrechtmatige overheidsdaad tidak dapat dilepaskan dari hukum administrasi baik secara teoritis maupun berdasarkan hukum positif. Oleh karena itu dibutuhkan hakim yang memiliki pemahaman terhadap ruang lingkup hukum administrasi ketika memeriksa perkara onrechtmatige overheidsdaad. ${ }^{22}$

\section{Penyelesaian Sengketa Batas Wilayah Antar Daerah Melalui Mahkamah Konstitusi}

Kasus yang dianalisis adalah Perkara nomor 1/SKLN-VIII/2010, antara Bupati Maluku Tengah dan Ketua Dewan Perwakilan Rakyat Daerah Maluku Tengah sebagai Pemohon terhadap Menteri Dalam Negeri Republik Indonesia sebagai pihak termohon. Pengucapan putusan pada hari Jumat tanggal 17 Maret 2011. Majelis Hakim yang memeriksa, mengadili dan memutuskan menyatakan "permohonan Pemohon tidak dapat diterima".

Terkait dengan sengketa kewenangan antar lembaga negara ini, berawal pada tanggal 15 Juli

\footnotetext{
${ }^{20} \mathrm{lbid}$

${ }^{21}$ Victor Emanuel W. Nalle, Konsep Uji Materiil Setara Press (Kelompok Intrans Publishing) Malang, Mei 2013, h.164

${ }^{22}$ Ibid, H.167
} 
2010 diregistrasi sebagai perkara sengketa kewenangan antar lembaga negara pada Mahkamah Konstitusi Republik Indonesia dengan nomor Perkara 1/SKLN-VIII/2010 antara Bupati Maluku Tengah dan Ketua Dewan Perwakilan Rakyat Daerah Maluku Tengah sebagai satu kesatuan Pemerintahan Daerah, yang mengajukan permohonan sengketa kewenangan sebagai pemohon terhadap Menteri Dalam Negeri Republik Indonesia sebagai pihak termohon. Sengketa kewenangan antar lembaga negara ini memiliki pokok yang disengketakan (objectum litis) yang merupakan kerugian konstitusional terhadap Pemerintahan Daerah Kabupaten Maluku Tengah.

Kerugian konstitusional ini merupakan kepentingan secara langsung sebagai akibat Menteri Dalam Negeri Republik Indonesia melakukan tindakan mengeluarkan Peraturan Menteri Dalam Negeri Nomor 29 tahun 2010 tentang Batas Daerah Kabupaten Seram Bagian Barat dengan Kabupaten Maluku Tengah Provinsi Maluku. Dalam putusannya yang dibacakan pada tanggal 17 Maret 2011, MKRI beranggapan bahwa subjectum litis dikaitkan dengan objectum litis permohonan pemohon bukan merupakan subjek maupun objek Sengketa Kewenangan Lembaga Negara (SKLN), maka menurut MKRI, permohonan pemohon tidak memenuhi ketentuan pasal 61 UU MK juncto. Pasal 2 Peraturan Mahkamah Konstitusi Nomor 8/PMK/2006, sehingga permohonan Pemohon tidak dapat diterima (nietonvankelijk verklaard).

Putusan MKRI yang menyatakan permohonan Pemohon tidak dapat diterima (niet onvankelijk verklaard) karena tidak memenuhi syarat pasal 61 UUMK merupakan putusan yang "final and binding" yang harus dihormati, diterima dan dijalankan. Namun, terhadap putusan MKRI terkait SKLN tidak menutup kemungkinan untuk diperdebatkan secara ilmiah hukum oleh siapapun. Hal ini disampaikan ketua MKRI yang menyatakan bahwa "adanya berbagai kajian ilmiah yang mengkritisi berbagai putusan MK dari berbagai disiplin keilmuan maupun pandangan niscaya sangat bermanfaat bagi kalangan internal Mahkamah Konstitusi untuk memahami bagaimana penilaian putusan itu dari kaca mata ilmu 
pengetahuan yang mengedepankan nilai kebenaran dan keadilan". ${ }^{23}$

Fakta hukum dengan dikeluarkannya Undang-Undang Nomor 40 tahun 2003 tentang Pembentukan Kabupaten Seram Bagian Timur, Kabupaten Seram Bagian Barat dan Kabupaten Kepulauan Aru di Provinsi Maluku telah menimbulakan multitafsir terhadap batas daerah antara kabupaten Seram Bagian Barat dengan kabupaten Maluku Tengah sebagai kabupaten induk. Multitafsir ini terkait dengan perbedaan rumusan pasal 7 ayat (2) huruf b Undang-Undang Nomor 40 tahun 2003 dengan lampiran II.

Penyelesaian hukum terhadap multitafsir ini telah dilakukan melalui judicial review terhadap Undang-undang Nomor 40 tahun 2003 yang dilakukan oleh MKRI. Melalui Putusan Nomor 123/PUU-VIII/2009, MKRI menyatakan bahwa "pasal 7 ayat (4) Undang-Undang nomor 40 tahun 2003 berikut penjelasannya dan lampiran II tentang batas wilayah kabupaten Seram Bagian Barat sepanjang menyangkut pasal 7 ayat (2) huruf b (Lembaran Negara Republik Indonesia tahun 2003 Nomor 155, tambahan Lembaran Negara Republik Indonesia Nomor 4350) bertentangan dengan Undang-undang Dasar Negara Republik Indonesia tahun 1945 dan tidak mempunyai kekuatan hukum mengikat".

Adanya putusan MKRI terkait dengan judicial review, seharusnya persoalan hukum batas daerah antara Kabupaten Seram Bagian Barat dengan Kabupaten Maluku Tengah telah berakhir karena sifat putusannya "final and binding". Implementasi putusan MKRI dalam hal teknis penetapan batas daerah oleh Menteri Dalam Negeri seharusnya didasarkan pada putusan dimaksud. Tetapi dengan dikeluarkannya Peraturan Menteri Dalam Negeri telah menimbulkan permasalahan hukum dengan adanya sengketa kewenangan lembaga negara.

Analisa terhadap putusan MKRI dalam perkara nomor 1/SKLN-VIII/2010 yang tidak menerima permohonan Pemohon (niet onvankelijk verklaard) diawali dengan kedudukan hukum (legal standing) para pihak yang berperkara, yaitu Bupati Maluku Tengah dan Ketua DPRD Maluku Tengah dengan Menteri Dalam Negeri. Dalam pasal 61 ayat (1) UU MK menyebutkan bahwa: "Pemohon adalah lembaga negara yang kewenangannya diberikan

\footnotetext{
${ }^{23}$ Sambutan Ketua Mahkamah Konstitusi pada penerbitan Jurnal Konstitusi, (Jurnal Konstitusi, Volume 1, Nomor 1, Juli 2004), h.5.
} 
oleh Undang-undang Dasar Negara Republik Indonesia tahun 1945 yang mempunyai kepentingan langsung terhadap kewenangan yang dipersengketakan". Terkait dengan rumusan norma hukum pasal 61 ayat (1) UUMK ini, muncul pertanyaan adalah lembaga manakah yang dapat dikategorikan sebagai lembaga negara?

Dalam UUDNRI tahun 1945 tidak terdapat satu pasalpun yang menguraikan apa itu lembaga negara. Secara konstitusional, istilah lembaga negara dapat ditemukan dalam pasal 24C ayat (1) UUDNRI tahun 1945 yang menyebutkan bahwa "Mahkamah Konstitusi berwenang mengadili pada tingkat pertama dan terakhir yang putusannya bersifat final untuk menguji undang-undang terhadap Undang-undang Dasar, memutus sengketa kewenangan lembaga negara yang kewenangannya diberikan oleh Undang-undang Dasar, memutus pembubaran partai politik dan memutus perselisihan tentang hasil pemilihan umum". ${ }^{24}$

Dalam UUDNRI tahun 1945 tidak memberikan perincian perihal lembaga- lembaga negara yang memiliki kualifikasi untuk maju dalam perkara Sengketa Kewenangan Lembaga Negara tersebut. Di dalam pasal 24C ayat (1) UUDNRI tahun 1945 hanya menetapkan kriteria lembaga negara yang memiliki legal standing tersebut. Kriteria itu adalah "lembaga negara yang kewenangannya diberikan oleh UUD". Demikian pula ketika kriteria itu dijabarkan dalam Undang-undang Nomor 24 tahun 2003 tidak disebut secara eksplisit mengenai jenis lembaga negara yang dimaksud Pasal 24C Ayat (1) UUDNRI tahun 1945. Di dalam pasal 61 ayat (1) UUMK disebutkan bahwa "pemohon adalah lembaga negara yang kewenangannya diberikan oleh Undang-Undang Dasar Negera Republik Indonesia tahun 1945 yang mempunyai kepentingan langsung terhadap kewenangan yang dipersengketakan".

Ketidakjelasan pengaturan lembaga negara akan menimbulkan terjadinya multitafsir, lembaga mana saja yang kewenangannya diberikan oleh UUD 1945. Hal ini lebih lanjut dikemukakan oleh Abdul Mukhtie Fadjar, yang menyatakan bahwa "persoalannya adalah bahwa baik UUD 1945, maupun UUMK tidak menyebutkan atau menjelaskan tentang apa

\footnotetext{
24 Perhatikan pasal 14C UUDNRI tahun 1945.
} 
yang dimaksud dengan "lembaga Negara yang kewenangannya diberikan oleh Undangundang Dasar" itu, sehingga bisa mengundang beberapa penafsiran, yaitu: ${ }^{25}$

a. Penafsiran luas, sehingga mencakup semua lembaga negara yang nama dan wewenangnya disebut/tercantum dalam UUD 1945;

b. Penafsiran moderat, yakni yang hanya membatasi pada apa yang dulu dikenal sebagai lembaga tertinggi dan tinggi negara;

c. Penafsiran sempit, yakni penafsiran yang merujuk secara implisit dari ketentuan pasal 67 UU MK.

Dapat dikatakan bahwa Bupati Maluku Tengah dan DPRD Maluku Tengah merupakan lembaga negara yang kewenangannya diberikan oleh UUD 1945, termasuk Menteri Dalam Negeri. Pokok yang disengketakan (objectum litis) dalam perkara nomor 1/SKLN-VIII/2010 terkait dengan "tindakan" Menteri Dalam Negeri dengan mengeluarkan Peraturan Menteri Dalam Negeri Nomor 29 tahun 2010 yang oleh pihak Pemohon (Bupati dan Ketua DPRD Maluku Tengah) bertentangan dengan Undang-undang Nomor 40 tahun 2003 sebagaimana telah diubah melalui putusan MKRI Nomor 123/PUU-VIII/2010. "Tindakan" mengeluarkan Peraturan Menteri Dalam Negeri ini menimbulkan kerugian bagi Pemerintah Daerah Kabupaten Maluku Tengah karena memiliki kepentingan secara langsung.

Amar putusan MKRI dalam perkara nomor 1/SKLN-VIII/2010 menyatakan bahwa permohonan Pemohon tidak dapat diterima (niet onvankelijk verklaard). Pertimbangan hukum MKRI bahwa objectum litis permohonan Pemohon bukanlah kewenangan pemohon yang diberikan oleh UUDNRI 1945, tetapi merupakan pertentangan antara Peraturan Menteri Dalam Negeri nomor 29 Tahun 2010 dengan Putusan MKRI Nomor 123/PUUVIII/2010. Apabila dianalisis, objectum litis yang memiliki keterkaitan dengan subjectum litis, pokok permohonan dalam perkaran nomor 1/SKLN-VIII/2010 terkait dengan "tindakan" yang dilakukan oleh Menteri Dalam Negeri dengan mengeluarkan Peraturan Menteri Dalam Negeri Nomor 29 tahun 2010. Objectum litis yang diajukan tidak diarahkan pada norma

\footnotetext{
${ }^{25}$ Abdul Mukhtie Fadjar, Hukum Konstitusi dan Mahkamah Konstitusi, (Jakarta, Konpress dan Yogyakarta, Citra Media, 2006,), h.183-184
} 
hukum (baik Peraturan Menteri Dalam Negeri maupun Putusan MKRI nomor 123/PUUVIII/2010), namun pokok sengketa kewenangan ini diarahkan pada "tindakan" yang dilakukan oleh pihak Termohon (Menteri Dalam Negeri). Sebagai lembaga negara yang kewenangannya diberikan oleh UUDNRI tahun 1945, Menteri Dalam Negeri merupakan lembaga negara yang kewenangannya diatur dalam pasal 17 UUDNRI tahun 1945. Dalam pasal 17 ayat (3) UUDNRI tahun 1945 ditegaskan bahwa "Setiap menteri membidangi urusan tertentu dalam pemerintahan", maka Menteri Dalam Negeri memiliki kewenangan konstitusional yang terakit dengan persoalan pelaksanaan pemerintahan di daerah. Tindakan yang dilakukan oleh Menteri Dalam Negeri dengan menerbitkan Peraturan Menteri Dalam Negeri merupakan "fungsi" yang dilakukan sebagai perwujudan dari wewenangnya. Fungsi yang dilakukan ini terkait dengan tujuan tertentu yang didasarkan pada wewenang. Dalam hal ini, Menteri Dalam Negeri melakukan fungsinya dengan menerbitkan Peraturan Menteri agar memperjelas tas daerah. Pelaksanaan fungsi Menteri ini harus didasarkan pada wewenang yang dimiliki. Terkait dengan fungsi, kedudukan, dan wewenang, Hasan Zaini mengatakan bahwa "fungsi, kedudukan dan wewenang memang sangat berkaitan. Fungsi dapat diartikan suatu lingkungan kerja untuk mencapai tujuan tertentu. Kedudukan suatu lembaga ditentukan oleh fungsinya. Untuk dapat menjalankan fungsinya dalam rangka mencapai tujuan tertentu, lembaga negara harus dilengkapi dengan wewenang (kekuasaan)". 26

Pertimbangan hukum MKRI dalam perkara nomor 1/SKLN-VIII/2010 lebih didasarkan pada pertentangan hukum antara Peraturan Menteri Dalam Negeri Nomor 29 tahun 2010 dengan Undang-Undang Nomor 40 tahun 2003 setelah putusan MKRI. Seyogyanya, pertimbangan hukum MKRI difokuskan pada tindakan yang dilakukan oleh Menteri Dalam Negeri melalui pembentukan Peraturan Menteri. Tindakan Menteri Dalam Negeri ini merupakan objectum litis yang semestinya merupakan pertimbangan hukum oleh MKRI, karena tindakan Menteri merupakan fungsi yang dilaksanakan berdasarkan kewenangan konstitusional sebagaimana diatur dalam UUDNRI tahun 1945.

Berdasarkan apa yang dikemukakan diatas, maka menjadi lebih elegan apabila MKRI dalam

${ }^{26}$ Hasan Zaini, Pengantar Hukum Tata Negara Indonesia, Alumni, Bandung, 1985, h.261 
menentukan objectum litis dan subjectum litis sebaiknya melakukan penafsiran terhadap sengketa kewenangan yang didasarkan tindakan lembaga negara sebagai pelaksanaan fungsi yang didasarkan pada kewenangan konstitusional, baik yang diatur dalam UUDNRI 1945 maupun dalam Undang- undang.

Dalam konteks sengketa batas wilayah antar daerah, penulis berpandangan bahwa Mahkamah Konstitusi sangat dimungkinkan untuk memberi putusan dengan berdimensi penemuan hukum, ini tentu saja bisa memberi harapan baru bagi Pemerintahan Daerah (yang terlibat sengketa batas wilayah antar daerah) untuk mendapatkan kepastian hukum dan keadilan.

Harus diakui bahwa penyelesaian SKLN di MKRI khususnya berkaitan dengan sengketa batas wilayah antar daerah (kontroversi apakah merupakan kewenangan asli atau kewenangan yang dibutuhkan), MKRI belum berani memunculkan putusan-putusan yang berdimensi penemuan hukum sedangkan dari sisi yang lain misalnya dalam hal pengujian undang-undang oleh MKRI tampaknya kecenderungan hakim konstitusi berani melakukan penafsiran di luar konstitusi (beyond the constitution) yang disertai dengan pendekatan perbandingan (comparative contitutional law) 27.

Penulis berasumsi, Mahkamah Konstitusi seharusnya mampu untuk menyelesaikan sengketa kewenangan lembaga negara termasuk berkaitan dengan sengketa batas wilayah antar daerah melalui putusan-putusan berdimensi penemuan hukum yang secara nyata nampak dalam terobosan hukum. Hakim Konstitusi bukanlah sekedar corong dari hukum tertulis, dengan diskresi yang dimiliki untuk melakukan penafsiran hukum, penulis yakin Mahkamah Konstitusi mampu memberikan solusi keadilan konstitusional yang substantif demi Kepentingan umum/daerah-daerah dalam konteks Negara Kesatuan Republik Indonesia. Hal ini menjadi penting demi melindungi wewenang konstitusional lembaga pemerintahan daerah yang sudah diberikan oleh UUDNRI 1945.

\footnotetext{
${ }^{27}$ Munafrizal Manan, Op.Cit, h.96, diambil dari Moh. Mahfud MD, Perdebatan Hukum Tata Negara Pasca Amandemen Konstitusi, Jakarta: LP3ES, 2007, h.42.
} 


\section{KESIMPULAN DAN SARAN}

\section{A. KESIMPULAN}

1. Penegasan batas daerah dalam pembentukan wilayah sangatlah urgen dalam pelaksanaan otonomi daerah. Karena tujuan dasar dari pembentukan Daerah Otonom Baru adalah mendekatkan pelayanan kepada masyarakat serta meningkatkan kesejahteraan masyarakat dengan batas-batas wilayah yang jelas. Tetapi implementasinya kebanyakan pemekaran daerah dimotivasi oleh kepentingan politis dan ekonomis. Kepentingan politik tersebut terkait dengan pengisian jabatanjabatan baru serta jabatan-jabatan lain di pemerintah daerah otonom baru nantinya. Sementara sisi ekonomis terkait dengan potensi sumber daya alam yang ada di daerah otonom baru tersebut, serta harapan akan mendapatkan alokasi dana oleh pemerintah pusat dalam pelaksanaan otonomi daerah.

2. Penyelesaian sengketa batas daerah dapat ditempuh melalui dua mekanisme, yakni: penyelesaian sengketa batas daerah secara non hukum dan penyelesaian sengketa melalui upaya hukum. Secara non hukum disebut juga penyelesaian sengketa melalui administrasi kepemerintahan, dalam hal ini dimediasi oleh Kementerian Dalam Negeri dan Gubernur. Sementara penyelesaian sengketa dengan upaya hukum ditempuh melalui gugatan yang diajukan oleh para pihak yang merasa dirugikan akibat terbitnya suatu keputusan atau peraturan ke Peradilan Tata Usaha Negara, Mahkamah Agung atau Mahkamah Konstitusi.

\section{B. SARAN}

1. Dengan tingginya kasus sengketa batas wilayah di daerah otonom baru sejak tahun 1999, maka sebaiknya ketentuan mengenai pemekaran daerah, memasukan persyaratan batas-batas daerah yang jelas lengkap dengan titik koordinat dalam undang-undang pemekaran daerah yang akan disahkan. Hal itu sangat mutlak diperlukan dalam pembentukan daerah otonomi baru, sehingga tidak menjadi persoalan dikemudian hari atau meminimalisir terjadinya sengketa. Serta perlu 
diperhatikan juga di dalam proses pembentukan daerah otonom baru dalam fase legislasi di Dewan Perwakilan Rakyat Republik Indonesia, Dewan Perwakilan Daerah Republik Indonesia maupun Kementerian Dalam Negeri Republik Indonesia, dapat memperhatikan muatan peran yang diberikan untuk partisipasinya yang luas dalam memberikan pertimbangan terhadap pembentukan Daerah Otonom Baru.

2. Untuk jangka waktu ke depan, demi menjamin kepastian hukum bagi penyelesaian sengketa batas wilayah antar daerah, pemerintah perlu didorong untuk merumuskan sebuah peraturan perundang-undangan yang secara tegas mengakomodasi arah penyelesaian hukum bagi sengketa batas wilayah antar daerah. 


\section{REFERENSI}

Abdullah, Rozali., Hukum Acara Peradilan Tata Usaha Negara, Cetakan Ketiga, Grafindo Persada, Jakarta,1994.

Asshiddiqie, Jimly., Perkembangan dan Konsolidasi Lembaga Negara Pasca Reformasi, Konpress, Jakarta, 2005.

Sengketa Kewenangan Antar Lembaga Negara, Konpress, Jakarta, 2005.

Atmosudirdjo, Prajudi., Hukum Administrasi Negara, Galla Indonesia, Jakarta, 1984.

Brandly, A. W., dan K. D. Ewing., Constitutional and Administrative Law,

Harlow: Pearson Education Limited, 2007.

Dicey, A. V., Introduction to the Study of the Law of the Constitution, Pengantar Studi Hukum Konstitusi, diterjemahkan oleh Nurhadi, Bandung: Nusantara Media, 2007.

Fadjar, Abdul Mukhtie., Hukum Konstitusi dan Mahkamah Konstitusi, Citra Media, Jakarta, 2006.

Hadjon, Phillipus M., Perlindungan Hukum Bagi Masyarakat di Indonesia: Sebuah Studi tentang Prinsip-Prinsipnya, Penanganannya oleh Pengadilan dalam Lingkungan Peradilan Umum dan Pembentukan Peradilan Administrasi, Peradaban, Surabaya, 2007.

Hakim, Lukman., Filosofi Kewenangan Organ Lembaga Daerah (Perspektif Teori Otonomi \& Desentralisasi dalam Penyelenggaraan Pemerintahan Negara Hukum dan Kesatuan), Setara Press, Malang, 2012.

Hoesein, Zainal Arifin., Judicial Review di Mahkamah Agung, Tiga Dekade Pengujian Peraturan Perundang-undangan, edisi 1 - cetakan 1, Divisi Buku Perguruan Tinggi Raja Grafindo Persada, Jakarta, 2009.

Ibrahim, Jhonny., Teori dan Metode Penelitian Hukum Normatif, Bayu Media Publishing, cet.2, Malang, 2006.

Lotulung, Paulus Effendi., Hukum Tata Usaha Negara dan Kekuasaan, Salemba Humanika, Jakarta, 2013.

Manan, Munafrizal., Penemuan Hukum oleh Mahkamah Konstitusi, Mandar Maju, Bandung, 2012.

Marbun, B. N., Otonomi Daerah 1945-2010 Proses \& Realita (Perkembangan Otda sejak zaman kolonial sampai saat ini), cetakan kedua edisi revisi 2010, Pustaka Sinar Harapan, Jakarta, 2010.

Marzuki, Peter Mahmud., Penelitian Hukum, cetakan ke-13, Jakarta, Kencana Prenada 
Media Group, 2017.

Meuwissen, D. H. M., Tentang Pengembanan Hukum, Ilmu Hukum, Teori Hukum, dan Filsafat Hukum, terjemahan oleh B. Arief Sidharta, Rafika Aditama, Bandung, 2007.

Murhani, Suriansyah., Aspek Hukum Pengawasan Pemerintah Daerah, Laksbang Mediatama, Cetakan 1, Malang 2008.

Nalle, Victor Imanuel W., Konsep Uji Materiil; Kajian Pembentukan dan Uji Materiil Peraturan Kebijakan di Indonesia, Setara Press, Malang-Jawa Timur, 2013. 